\title{
Publicar em revistas lusófonas: Uma meta para uma academia consolidada
}

\author{
J. Vasconcelos-Raposo, C.M. Teixeira
}

Direç̧ão da Revista Motricidade - Universidade de Trás-os-Montes e Alto Douro

Os discursos políticos dos governantes, com alguma regularidade, aludem à crescente presença de investigadores Lusófonos na literatura internacional publicada em língua inglesa, assim como ao crescente número de doutores que vão sendo formados anualmente. Tudo isto se afirma e se utiliza, de forma mais ou menos eficaz, como demonstração das boas acções governativas. Na realidade, há alguma factualidade nessas afirmações e reconhecemos que têm sido concebidas estratégias políticas que visam incentivar os investigadores a publicar com maior regularidade, mas preferencialmente em revistas anglo-saxónicas. Estes incentivos são acompanhados de práticas avaliativas, que têm ocorrido com regularidade, tal como se deseja. Os investigadores, e os centros de pesquisa a que pertencem, são periodicamente sujeitos a avaliações externas, cujos "panelistas" são, na sua maioria, oriundos de países estrangeiros e que não sabem falar, nem ler português.

A história recente da intervenção destas comissões de avaliação, no caso de Portugal, tem evidenciado alguns problemas, e desencadeado reacções de repúdio por parte dos que têm sido avaliados, por considerarem inadequados os parâmetros tidos em consideração, assim como as fundamentações apresentadas para as classificações atri- buídas, que por serem desajustadas à realidade do sistema universitário em apreço se poderiam designar, tal como Comte o fez em tempo, de serem fruto de uma pedantocracia. Entre outros aspectos, que se apresentam questionáveis, é referido o facto de, na elaboração dos seus relatórios, as comissões negligenciarem as publicações em revistas de língua portuguesa, independentemente da classificação e indexação que possam ter. A esta prática a tutela responsável pelo financiamento de uma parcela acentuada dos projectos realizados no país mantém uma posição passiva, apesar de concordar em alterar as classificações atribuídas. A praxis da instituição financiadora requer reflexão a vários níveis, mas enquanto editor de uma revista limitar-me-ei a olhar ao fenómeno na perspectiva da Revista Científica.

Vai para séculos que a educação tem sido objecto de preocupação dos que governam. Em nome do que é melhor para o povo, aqueles que detêm o poder procuram implementar politicas de ensino que na sua essência pouco mais são do que estratégias para exercer e manter o controlo social colocando a Educação ao serviço de forças alheias aos interesses reais do Povo. Tais práticas não deixam margem para dúvidas que a educação é um instrumento ideológico que não pode ser 
descurado. Com o desenvolvimento industrial, tal como aconteceu, fundamentalmente, nos países de língua saxónica, e a procura sistemática por mais-valias e a consequente necessidade de alargamento da oferta de produtos de consumo para a manutenção e crescimento de riqueza, tornou-se necessário massificar a educação e com ela a prática científica. Como consequência desta visão privilegiam-se os financiamentos para as áreas em que novos produtos possam emergir, para assim se sustentar as necessidades básicas do sistema que "alimenta" a economia de mercado. A economia de mercado, cada vez mais, depende das relações que estabelece entre o sector industrial e a comunidade científica, cujos conhecimentos carecem de larga divulgação, para que seja possível assegurar um esforço que se deseja cooperativo e, consequentemente, construído com base na partilha dos saberes gradual e por vezes sectorialmente acumulados. É neste processo de partilha e divulgação que as revistas científicas ganham relevância, na medida em que é através delas que os investigadores podem participar e até beneficiar da sua pertença à comunidade científica.

A ideia de uma comunidade científica alargada é algo que atrai todos aqueles que acreditam no processo de partilha do saber e que através da ciência é possível proporcionar melhores condições vida às populações. A importância do domínio da linguagem é algo de fundamental para a partilha dos saberes e isto é algo de inquestionável. No entanto, já não faz sentido que tenham de ser todas as nacionali- dades a ter de aprender e a dominar o inglês para essa partilha. Ao se defender a ideia comunidade científica internacional deveremos ter por base expectativas de empenho de todos, independentemente das nacionalidades em causa. Assim, deverá ser expectável que uns aprendam inglês e outros espanhol, português, francês, etc., e com base nessas línguas se proceda à partilha dos saberes. Mas não é isso que acontece. Aparentemente, os investigadores anglo-saxónicos podem apresentar-se como deficientes nas suas capacidades de aprendizagem de outras línguas, mas aos "outros" é exigido demonstrar uma dupla superioridade intelectual, pois para além de terem de dominar os conhecimentos científicos, tal como os outros, têm também de ultrapassar as aparentes limitações dos investigadores anglo-saxónicos, como se estes fossem incapazes de aprender uma língua para além da sua materna. Mas neste tipo de situação o argumento poderia ser diferente, na medida em que transparece uma lógica de relacionamento em que uns aparentam ser os donos da ciência e os outros apenas indivíduos cuja ambição os leva a querer ser "os outros"... e para o conseguirem estão predispostos a negligenciar o que têm de bom para, por vezes, aceitar qualquer padrão desde que venha dos que mandam.

Tudo isto seria simples se os governos financiassem comunidades científicas que se dedicassem exclusivamente à pesquisa, mas a realidade não é essa. Aquilo que se impõe é que os investigadores sejam simultaneamente docentes e pesquisadores. 
Como docentes todos têm de assumir a responsabilidade de formar a nova geração de governantes e pensadores, mas essa leccionação faz-se na língua materna e em raros países se constata a excepção da ocorrência de uma aprendizagem do inglês desde cedo no sistema escolar. Mas será que nesses países os jovens chegam ao ensino superior com níveis de proficiência linguística suficiente? A julgar pela qualidade dos resumos em inglês que nos chegam diria que não, pelo menos nos países Lusófonos. Então, como conciliar este aparente conflito de interesses? Por um lado é desejado aumentar a presença nas revistas anglosaxónicas mas, por outro, não se pode deixar de dar resposta às políticas de formação universitária, onde as horas que restam para que os docentes se dediquem à pesquisa são poucas.

Face às limitações financeiras dos países em desenvolvimento, os académicos/investigadores esforçam-se por compreender a implementação de alguma racionalização na distribuição das verbas do Estado e manifestam-se tolerantes quanto à escassez de meios para a pesquisa. No entanto, quando este esforço em posto em causa e quando é dado a constatar avultados investimentos com instituições universitárias estrangeiras, e que na prática, representam mais despesa do que ganhos para a comunidade científica, assim como para o países em causa, esta tolerância deverá merecer o repúdio por parte dos pesquisadores. Um outro aspecto que nos confunde nas políticas de apoio à comunidade científica prende-se com o facto de as agên- cias, no caso de Portugal uma Fundação, financiarem a criação e manutenção de revistas científicas, para depois assistirem passivamente às acções das comissões de avaliação externa, que por falta de formação cultural são incapazes de ler outra língua que não seja a sua, a relegarem para segundo plano o que se produz e publica em língua portuguesa, tanto em Portugal, como no Brasil ou em outros países Lusófonos.

Afinal, ao serviço de quem deveremos estar? Será possível participar no processo de integração na comunidade internacional e ao mesmo tempo servir as necessidades dos jovens ainda em formação e, por meio dessa mesma missão, prestar um serviço relevante às comunidades Lusófonas?

Enquanto responsável pela gestão da Revista Motricidade, na qualidade de editor as respostas às perguntas são as seguintes: 1- estamos ao serviço da Ciência e dos Povos; 2- enquanto revista, concomitantemente, prestamos um serviço comunidade científica internacional e aos jovens em formação, proporcionando-lhes um meio para beneficiarem da bondade dos mais experientes que dedicam o seu tempo a rever trabalhos e a dar-lhes feedback, assim como a partilhar o mesmo espaço de divulgação do conhecimento.

No actual contexto, é inegável que as revistas científicas são, também, um instrumento da ideologia subjectiva que tende a tipificar a economia de mercado. Mas importa que tenhamos consciência do papel que desempenhamos, enquanto agentes difusores de conhecimento, na consolidação de processos próprios de sociedades democrá- 
ticas que visem salvaguardar os interesses e o bem-estar dos Povos. Para isso, e sempre que julgarmos necessário, devemos intervir, activamente, em defesa do que consideramos importante na construção de sociedades mais justas e isso, inevitavelmente, requer que tenhamos a capacidade intelectual suficiente para poder defender o que de melhor oferecemos.

Em verdade, enquanto Lusófonos, integramos uma comunidade científica que tende a se auto-menosprezar. Por exemplo, o Estado Brasileiro e o Português têm investido na plataforma Scielo, que se caracteriza por proporcionar acesso livre a toda a criação de saber que as suas revistas disponibilizam e sem qualquer tipo de encargo financeiro para quem dela deseja beneficiar. No entanto, há académicos que continuam a privilegiar publicar em revistas que integram o património de empresas multinacionais, cujo negócio é gerar lucros com base nos trabalhos que esses lhes proporcionam livremente e, casos há em que os pesquisadores pagam às revistas para que publiquem os seus trabalhos e fazem-no cedendo os direitos de autor. As revistas, para sustentarem os seus negócios, delegam os direitos às multinacionais que, com essa matéria-prima, fazem o seu negócio.

Enquanto Director de uma revista, tenho por obrigação promover todas as iniciativas que levem a Motricidade a integrar o maior número de bases de indexação possíveis. Estou ciente que há umas mais prestígio que outras. Mas, na essência, o que mais importa é contribuirmos para que o número de revistas em língua portuguesa que integram essas bases cresça, pois só assim estaremos a colaborar activamente no processo de afirmação internacional do conhecimento científico gerado por aqueles que confiaram em nós para levarmos o mais longe possível os seus contributos. 